\title{
INCORPORATING TIMBER EDUCATION INTO EXISTING ACCREDITEd EngINEERING Programs
}

\author{
Bronwyn Chorlton, Natalie Mazur, and John Gales* \\ York University \\ *jgales@yorku.ca
}

\begin{abstract}
The demand for large and tall timber buildings is increasing across Canada. The recently constructed Brock Commons building in Vancouver and the upcoming Arbour building in Toronto are two such examples. These buildings are challenging for practitioners to design, and presently only a limited number of engineering institutions across Canada offer a course in timber design. There is a growing demand for engineering graduates who can contribute to the creation of these structures; however, the number of graduates who meet this criterion is lagging. Separate courses in timber could be introduced to more universities, however the addition of a new course may overload students, whose course schedules are already tightly regulated by the Canadian Engineering Accreditation Board. Moreover, the creation of a new course can take several years and will therefore not meet the current industry demand quick enough.
\end{abstract}

The research herein presents a method of incorporating timber education within the existing civil engineering curriculum in Canada, without the introduction of an additional course. The purpose of the proposed method is to offer an efficient solution that will provide engineering students with knowledge of the timber industry quickly to meet industry demand. Two timber learning modules were integrated within the existing Structural Steel Design course at an accredited university. The timber learning modules paralleled the topics covered within an undergraduate timber design course. Students were surveyed before and after the learning modules were presented to assess level of interest and motivations, knowledge of the industry, and level of understanding. After the learning modules were presented, $76 \%$ of students indicated they had some level of confidence in contributing to the design of a timber building. These results show that the timber learning modules were successful at introducing and generating an interest in timber design, and that students gained basic knowledge they could apply in practice.

Keywords: Timber education, engineering accreditation, learning modules

\section{INTRODUCTION AND BACKGROUND}

Timber construction is becoming increasingly popular across Canada. Coast to coast, buildings such as the Brock Commons building in Vancouver have been constructed, and numerous others such as Toronto's Arbour Building are in progress. Moreover, the proposed changes to the upcoming National Building Code of Canada (NBCC) 2020 includes allowances for taller and more exposed timber structures [2]. With this growing demand for timber construction, there is a need for timber education in engineering programs, which is currently lagging behind the industry demand and momentum. Timber is a building material with many unique properties not typically considered in reinforced concrete or steel construction, often resulting in a highly complex design. In order for practitioners to keep up with the requests for these timber structures, timber design needs to be taught broadly across accredited civil engineering programs.

There are a number of methods which may be carried out to ensure that students have the required knowledge to fulfil the industry demand. While some schools have already successfully been able to offer a timber design course or other means of timber education to their students, a significant number have not yet been able to. This paper will discuss methods of educating students on timber at schools which have not yet implemented these courses or programs.

One option to educate students regarding timber is to introduce a timber course into undergraduate engineering programs. There are a number of teaching resources to facilitate the creation of a timber course provided by the Canadian Wood Council (CWC), including a series of free presentations that an instructor could adapt and deliver to their students [5]. The timber design handbook is also easily attainable and would further facilitate structuring a timber design course. A course outline for a typical undergraduate timber design course has also been developed by the CWC and is summarized in Table 1. A drawback of this method is that it can take many years to introduce a new engineering design course at a university, and graduates who can design timber are needed in industry immediately. Further, the addition of another 
design course can overload students, whose curriculums have already been rigidly constructed to meet existing Canadian Engineering Accreditation Board (CEAB) requirements.

Table 1: Outline of an undergraduate timber design course.

\begin{tabular}{|c|c|}
\hline Topic & Description \\
\hline Introduction & $\begin{array}{l}\text { Wood as a green building } \\
\text { material; History of wood } \\
\text { structures }\end{array}$ \\
\hline $\begin{array}{l}\text { Physical and mechanical } \\
\text { properties of wood }\end{array}$ & $\begin{array}{l}\text { Molecular and cell } \\
\text { structure; Physical } \\
\text { properties; Mechanical } \\
\text { properties }\end{array}$ \\
\hline $\begin{array}{l}\text { Structural Wood } \\
\text { Products \& Structural } \\
\text { Forms }\end{array}$ & $\begin{array}{l}\text { Dimensional shapes; } \\
\text { Engineered wood } \\
\text { products }\end{array}$ \\
\hline $\begin{array}{l}\text { Strength and } \\
\text { modification factors }\end{array}$ & $\begin{array}{l}\text { Specified strength of } \\
\text { wood, size, use, species } \\
\text { and grade; Modification } \\
\text { factors; Shrinkage } \\
\text { calculation }\end{array}$ \\
\hline Design Process & $\begin{array}{l}\text { Limit states design- } \\
\text { ultimate \& serviceability } \\
\text { limit states }\end{array}$ \\
\hline $\begin{array}{l}\text { Design of tension } \\
\text { members }\end{array}$ & $N / A$ \\
\hline $\begin{array}{l}\text { Design of compression } \\
\text { members }\end{array}$ & $N / A$ \\
\hline $\begin{array}{l}\text { Design of bending } \\
\text { members }\end{array}$ & $\begin{array}{l}\text { Solid lumber beams, } \\
\text { joists, planks; Glulam- } \\
\text { straight prismatic beams, } \\
\text { tapered straight beams }\end{array}$ \\
\hline Fire safety & $\begin{array}{l}\text { Mechanics of wood in } \\
\text { fire; Code procedures; } \\
\text { Encapsulation }\end{array}$ \\
\hline $\begin{array}{l}\text { Combined bending and } \\
\text { axial load }\end{array}$ & $N / A$ \\
\hline \multirow[t]{2}{*}{ Connections } & Nails and spikes \\
\hline & Bolts and lag screws \\
\hline $\begin{array}{l}\text { Lateral loading and } \\
\text { design }\end{array}$ & Shear walls/diaphragms \\
\hline
\end{tabular}

This raises the question of how universities can educate their civil engineering graduates on timber design quickly, without overloading students and still meeting CEAB accreditation requirements. The purpose of the research herein is to provide an overview of an alternative method to educate civil engineering students on timber design, by implementing a series of timber modules into existing civil engineering courses. This method has been implemented at one accredited university, where the learning modules have been introduced within the Structural Steel Design Course on a trial basis.
Furthermore, in this course, a number of different trial teaching methods were used (some of which are beyond the scope of the paper to describe), allowing for not only the attainment of the required graduate attributes but also the inclusion of attributes beyond those required.

\section{MOTIVATION}

\subsection{Integration of timber learning modules into existing courses}

In order to be integrated into existing courses within the civil engineering curriculum, the course outline presented in Table 1 has been broken down into two learning modules. The first learning module (Module 1) consists of the first four topics listed in Table 1, beginning with the Introduction and ending with Strength and Modification Factors. The second learning module (Module 2) covers the remaining topics, focusing therefore primarily on timber design. Once these learning modules have been outlined, the question then becomes where these modules can be presented in the curriculum. One course that offers a prime opportunity for the integration of timber is Structural Steel Design. A sample course outline for an undergraduate Structural Steel Design course is seen in Table 2. This is a common outline used for the Structural Steel Design course. From comparing both Table 1 and Table 2, it becomes clear that there is significant overlap between the two courses in design methodologies and themes. Many of the skills and topics students are learning about in their steel design courses become easily transferrable to timber design, allowing for a quicker introduction to the topics than if they were introduced in two separate courses.

Table 2: Outline of an undergraduate steel design course.

\begin{tabular}{|l|l|}
\hline Topics & Subtopics \\
\hline Introduction & $\begin{array}{l}\text { Background into } \\
\text { structural steel; Limit } \\
\text { states design - ultimate \& } \\
\text { serviceability limit states }\end{array}$ \\
\hline $\begin{array}{l}\text { Design of tension } \\
\text { members }\end{array}$ & N/A \\
\hline $\begin{array}{l}\text { Design of compression } \\
\text { members }\end{array}$ & N/A \\
\hline $\begin{array}{l}\text { Design of bending } \\
\text { members }\end{array}$ & N/A \\
\hline $\begin{array}{l}\text { Design of Beam } \\
\text { Columns }\end{array}$ & N/A \\
\hline $\begin{array}{l}\text { Corrosion } \\
\text { Causes, effects and } \\
\text { prevention of corrosion; } \\
\text { Case studies }\end{array}$ \\
\hline Connections & Welds; Bolts and rivets \\
\hline Composites & $\begin{array}{l}\text { Composite beams; } \\
\text { Composite decks }\end{array}$ \\
\hline
\end{tabular}


Other courses also present opportunities to implement timber learning modules. An example of this would be a Civil Engineering Materials course. Both the Structural Steel Design course and the Civil Engineering Materials course are nearly universally offered in civil engineering programs across Canada.

These courses show that there are many opportunities to integrate timber design within existing engineering courses. One method of presenting the timber modules could be to present Module 1 in the Civil Engineering Materials course, and to present Module 2 in the Structural Steel Design course. An advantage of this approach is that Civil Engineering Materials is often a lower year course (while Structural Steel Design is often taught to upper years). This gives lower year students an introduction to the material. Module 1 also coincides well with the existing topics in Civil Engineering Materials, as does Module 2 with the existing topics in Structural Steel Design. This method would necessitate having the Civil Engineering Materials course as a pre-requisite to the Structural Steel Design course, so that students learn the modules sequentially. Alternatively, both learning modules could be presented in the same course. In this case, the course would likely be an upper year course, such as Structural Steel Design, so that students would already have a strong background in materials and structural design.

\subsection{Graduate Attributes}

In developing engineering courses at CEAB accredited institutions, the graduate attributes are carefully considered for each course (see [3]). While each course must meet their required graduate attributes, additional graduate attributes may also be met. There are a number of simple ways in which additional graduate attributes may be met. Within the Structural Steel Design course, many different teaching methods were used to meet and even exceed the required graduate attributes. This can be seen in Table 3. While these methods touched on a number of different graduate attributes, these graduate attributes were largely unmeasured and unassessed. The teaching methods described below were largely introductory and exploratory procedures, many of which could easily be assessed in future installments of the course.

Students were required to research a steel building of their choosing and self-record a presentation. The requirements of this presentation allowed for many additional graduate attributes to be met, including communication skills, and economics and project management (to name just a few). Additionally, experiential learning took place through the form of site visits. The sites that were visited included new construction, heritage buildings, and buildings undergoing demolition. This allowed students to see the full life cycle of a steel structure and touched on graduate attributes such as impact on society and the environment as well as lifelong learning.
Due to the importance of equity, diversity and inclusivity within engineering, the paper's second author, who focuses on these topics, was asked to present a lecture on the current state of diversity within the engineering education system and profession, and to suggest skills that students can use to help create an inclusive environment. This addressed the graduate attributes of ethics and equity, and impact on society and the environment, for example. Finally, students also worked in groups for their mid-term evaluations, which is representative of what may occur when they enter the workforce. This incorporated the communication skills and individual and team work graduate attributes.

Table 3: Graduate attributes required and met or explored for the Structural Steel Design Course.

\begin{tabular}{|l|l|l|}
\hline $\begin{array}{l}\text { Graduate } \\
\text { Attribute }\end{array}$ & $\begin{array}{l}\text { Required } \\
\text { (Yes/No) }\end{array}$ & $\begin{array}{l}\text { Met or } \\
\text { Explored } \\
\text { (Yes/No) }\end{array}$ \\
\hline Knowledge base & Yes & Yes \\
\hline Problem analysis & Yes & Yes \\
\hline Investigation & No & No \\
\hline Design & Yes & Yes \\
\hline Engineering tools & Yes & Yes \\
\hline $\begin{array}{l}\text { Individual and } \\
\text { team work }\end{array}$ & No & Yes \\
\hline $\begin{array}{l}\text { Communication } \\
\text { skills }\end{array}$ & No & Yes \\
\hline $\begin{array}{l}\text { Impact on society } \\
\text { and the } \\
\text { environment }\end{array}$ & No & Yes \\
\hline Ethics and equity & No & Yes \\
\hline $\begin{array}{l}\text { Economics and } \\
\text { project } \\
\text { management }\end{array}$ & No & Yes \\
\hline Life-long learning & No & Yes \\
\hline
\end{tabular}

\section{METHODOLOGY}

The two timber modules previously outlined were integrated into the Structural Steel Design course at an accredited engineering institution in Ontario during the Winter 2019 semester. 32 students were enrolled in the course, all within the civil engineering program. The learning modules were introduced to the students over two, three-hour sessions. Most of the topics outlined in Table 1 were presented within these sessions, however, where the content was extremely similar or identical content already covered within the steel lectures, students were expected to transfer their knowledge to timber applications. To the authors' knowledge and based on feedback from the students, the students had never previously been introduced to timber as a building material within their undergraduate education. At this particular institution, the timber Module 1 was also introduced into the Civil Engineering Materials course in the same academic year, however, the fourth-year 
students enrolled in the Structural Steel Design course did not have this previous exposure (necessitating both timber modules to be introduced in the same course, until the students who learned Module 1 in the Civil Engineering Materials course progress to the Structural Steel Design course).

Students were surveyed both before and after the learning modules were presented. Participation of the students was voluntary. Students were provided with a link to an online survey platform, where they could complete the survey using a laptop or mobile device. Of the 32 students enrolled in the course, 29 chose to participate in the surveys (91\%). Students were not penalized for not filling out the survey. The survey was meant to gauge student motivations, level of interest, and knowledge. The full 15 question survey is presented in the Appendix of this paper.

\subsection{Graduate Attributes}

Several survey questions align with the graduate attributes. The purpose of the survey was not to evaluate graduate attributes, but many of the survey questions reflect these areas nevertheless. More formal assessments were used in the course to measure graduate attributes.

'A knowledge base for engineering' is one graduate attribute that was addressed by the survey. Several questions asked students to use their specialized engineering knowledge. Questions 9-13 (Appendix A) are all based on the students' engineering fundamentals and specialized engineering knowledge, as they ask knowledge-based questions about timber products, industry trends, and timber design.

Next, 'impact of engineering on society and the environment' is another graduate attribute dealt with in the survey. Construction materials have a significant impact on the environment, and they impact society through social, health and safety, and cultural means. These considerations apply to timber as it is a material that can be harvested and manufactured relatively sustainably. Further, in a social and health context, it has been shown that there are psychological and physiological health benefits of occupying a timber building $[1,4]$. There are also several unique challenges that must be addressed in timber construction to assure life safety - for instance, its combustible nature requires significant considerations for its fire design. Several of the survey questions solicited responses from the students regarding these topics. Questions 5-6 and 12-13 (Appendix A) all asked students to reflect on the impact of timber construction on the society and the environment.

The final graduate attribute that will be discussed is 'economics and project management'. As a building material, timber is typically characterized as being expensive but fast to construct (relative to reinforced concrete and steel). Survey questions 5-6 and 12-13 asked the students to reflect on these economics and project management principles (Appendix A).

\section{RESULTS AND DISCUSSION}

A number of survey question results showed differences before and after the learning modules were presented; however, other questions showed no difference. The following subsections will examine some of the findings.

\subsection{Thoughts of Industry and Trends}

Students were surveyed to evaluate their knowledge and opinions of the timber industry. The results of one question, gauging student support of more tall and large timber buildings, is seen in Figure 1.

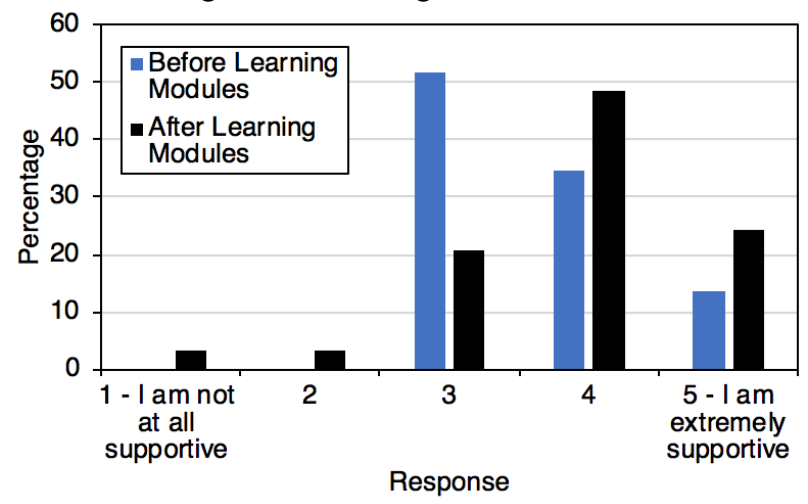

Fig. 1. Distribution of responses to the question, "How much do you support the construction of more tall and large timber buildings?"

From Figure 1, it can be seen that before the learning modules, $52 \%$ of students selected a neutral response. This neutral response reflects the little knowledge students had regarding timber construction prior to the presentation of the learning modules. After the presentation of the learning modules, students were more opinionated. Only $21 \%$ were neutral, with the rest of the students indicating that they were either supportive (72\%) or not supportive (7\%). This indicates that the learning modules were successful in providing the students with knowledge regarding timber construction, and this knowledge was sufficient for them to form an opinion where they were previously neutral.

As a follow up, students were asked why they supported/did not support the construction of more tall and large timber buildings. There were no significant differences in their reasoning before and after the presentation of the learning modules. The most common reasons students were in support were sustainability and architectural reasons. The most common reasons students were not in support were concerns about fire, pests, sustainability, limited guidance available, deterioration, and architecture.

Students were also asked about their predictions regarding the construction of more tall and large timber 
buildings, in both Toronto and Canada. For both questions, students predicted significantly or slightly more large and tall timber buildings, more frequently after the learning modules had been presented. The student's responses regarding the construction of tall and large timber buildings in Toronto is seen in Figure 2.

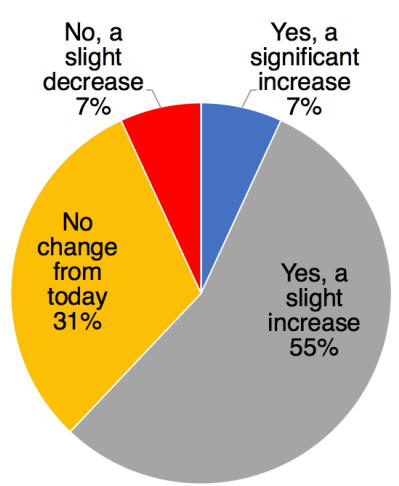

Before learning modules

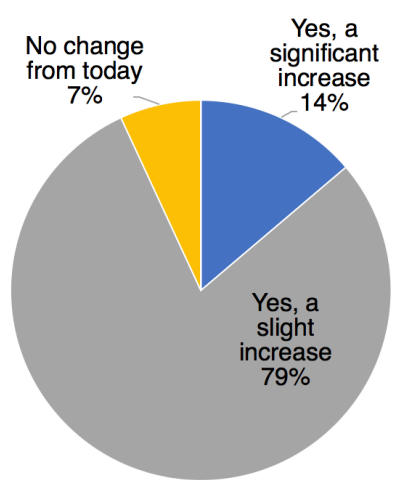

After learning modules
Fig. 2. Distribution of responses to the question, "Do you think we will see an increase in the number of timber buildings being constructed in the next few years in Toronto?" before the learning modules, left, and after the learning modules, right

Students were also asked to name any engineered timber buildings in Toronto or Canada. 16 students (55\%) were able to name a building before the presentation of the learning modules, compared to 21 students $(72 \%)$ afterwards. The most common buildings both before and after the learning modules were Brock Commons, Origine, 80 Atlantic Ave, and the Arbour building. These results suggest that the timber learning modules helped students to become more familiar with Canadian applications of timber design.

\subsection{Level of Knowledge}

The survey asked questions with the intention of gauging how much knowledge students had regarding timber before and after presentation of the learning modules. These were not meant to be difficult questions for the students but were simply meant to give an idea of the level of understanding.

Students were asked how familiar they were with existing engineered timber products. The distribution of responses is seen in Figure 3. It is clear that before presentation of the learning modules, there was little knowledge of engineered timber products, with $45 \%$ of students responding that they were not familiar at all. Only $24 \%$ of students rated their knowledge at a 3 or higher (with 1 being not at all familiar, and 5 being very familiar) before the presentation of the learning modules. After the learning modules were presented, $86 \%$ of students rated their knowledge as a 3 or more. In addition, students were also asked "What is engineered timber?" as an open-ended question. Responses were classified as correct relatively generously, if students were able to at all describe what constitutes engineered timber. Before presentation of the learning modules, 8 students $(28 \%)$ answered correctly, and afterwards 18 students (62\%) answered correctly.

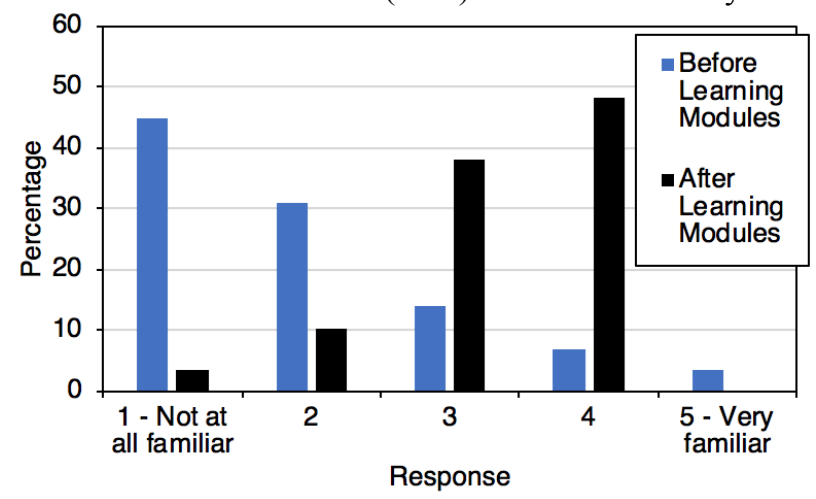

Fig. 3. Distribution of responses to the question, "How familiar are you with different timber products, for example, Cross Laminated Timber, Glued Laminated Timber, etc.?"

The level of student knowledge was also assessed by asking students to explain two or three advantages and disadvantages of timber construction. $69 \%$ of students were able to explain two or more advantages before the presentation of the learning modules, compared to $83 \%$ afterwards. The most common advantages listed included lightweight, sustainable, architecturally pleasing, and fast construction. After the learning modules were presented, there were additional answers regarding material durability. In terms of disadvantages, $69 \%$ of students were able to correctly identify two or more before the learning modules, compared to $79 \%$ afterwards. The students listed a wide variety of disadvantages, with the most common being concerns about fire, moisture, vibration, sustainability, maintenance, material defects, acoustics, pests, and fungi/rot. After the learning modules were presented, student answers also included strength perpendicular to the grain and high cost. Overwhelmingly in both surveys, fire and moisture control were the largest sources of concern.

Student responses to all of the questions assessing level of knowledge give indication that the learning modules were successful in providing the students with some general knowledge of timber. Every question asked showed an improvement in quantity of correct answers, or an improvement in students' self-assessment of their own level of knowledge.

\subsection{Level of Interest and Motivation to Study Timber}

A number of questions were asked to assess the interest levels and motivations of the students to study timber design. First, students were asked why they were interested in or disinterested in timber design. There were 
no significant differences before and after presentation of the learning modules. Mostly, students were interested because they think it aligns with industry trends and will be useful as they enter the workforce. Some students also mentioned that they like the sustainability aspects, and others noted that they were simply curious because they had not yet learned about timber. Students were asked to quantify how interested they would be in learning more about timber within their civil engineering education, on a scale of 1-5 (with 1 being not interested and 5 being extremely interested). Before the learning modules, $86 \%$ of students ranked their interest level as a 4 or a 5 , and after the learning modules $97 \%$ of students ranked their interest level as a 4 or a 5 . This shows that students are highly interested in learning more about timber design even with no prior introduction, and that the learning modules only sparked a further interest in the students.

Students were then asked, if given the option to take one of either steel design, timber design, or a hybrid steel and timber design course, which would they select. Their responses are seen in Figure 4. Both before and after the learning modules, students were very keen on a hybrid steel design course. Before the learning modules, the second most favoured course was steel design. After the learning modules, while the hybrid course remained the favourite, the timber design course became the second most chosen option. This may show that the learning modules helped the students to see the importance and applicability of timber design. The fact that in both surveys students favoured the hybrid course reinforces the student desire for timber education.

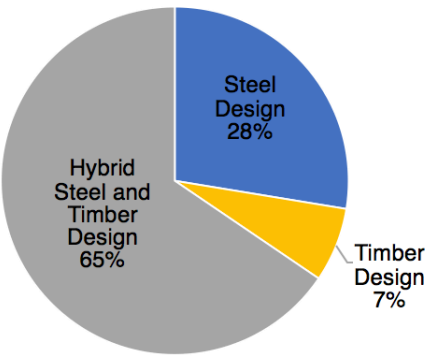

Before learning modules

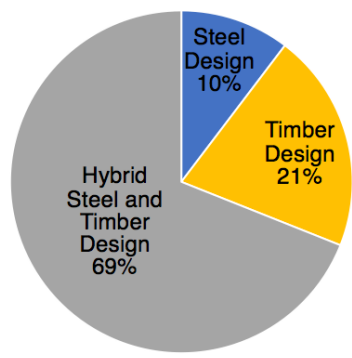

After learning modules

Fig. 4. Distribution of responses to the question, "If you had the option of taking one of the following courses, which one would you choose?" before the learning modules, left, and after the learning modules, right

\subsection{Other results}

Other miscellaneous topics covered include student self-confidence in contributing to the design of a timber building upon graduation. The results of this question are seen in Figure 5. Students were able to rank their confidence level from 1 to 5 , with 1 being not confident at all and 5 being very confident. Before the learning modules, only $55 \%$ of students ranked their confidence as a 3 or more, compared to $76 \%$ of students after the learning modules. Furthermore, $28 \%$ of students initially indicated that they were not confident at all. After the learning modules, no students selected this response, indicating that all students had at least some level of confidence.

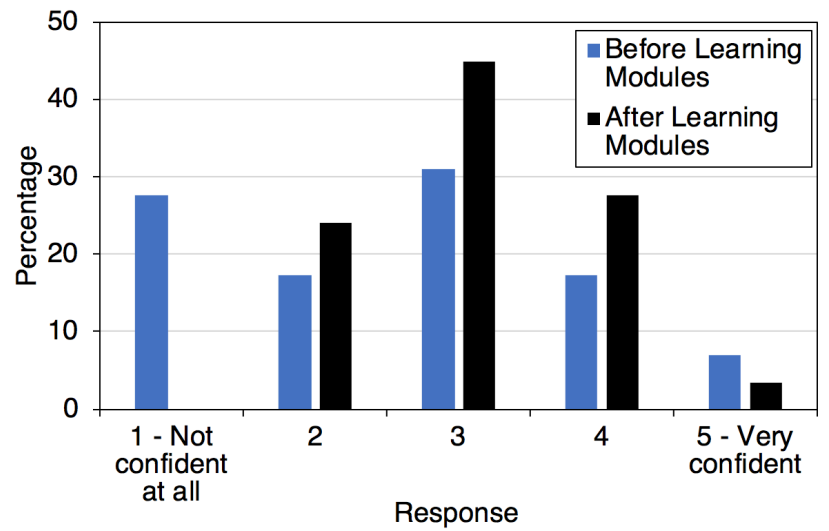

Fig. 5. Distribution of responses to the question, "Upon graduation, how confident would you be contributing to the design of a timber building?"

The final question that will be discussed gave the students the chance to state any remaining thoughts. The question asked, "Do you have any other opinions about timber education or the timber industry in Canada that you would like to share?". This question was asked only after the learning modules were presented. Largely, students took the opportunity to re-express their interest in further learning opportunities. A summary of their responses is seen in Table 4.

Table 4: Responses to the question, "Do you have any other opinions about timber education or the timber industry in Canada that you would like to share?"

\begin{tabular}{|l|l|}
\hline Response & Count \\
\hline $\begin{array}{l}\text { Stated an interest in a separate } \\
\text { timber course or further integration } \\
\text { into the engineering curriculum }\end{array}$ & $15(52 \%)$ \\
\hline $\begin{array}{l}\text { Stated an interest in learning more } \\
\text { about timber without mention of an } \\
\text { additional course or the engineering } \\
\text { curriculum }\end{array}$ & $4(14 \%)$ \\
\hline Discussed sustainability & $1(3 \%)$ \\
\hline $\begin{array}{l}\text { Stated a disinterest in learning more } \\
\text { about timber }\end{array}$ & $1(3 \%)$ \\
\hline No further opinions & $8(28 \%)$ \\
\hline
\end{tabular}

\subsection{Graduate attributes}

The results of the survey also showed that the learning modules were useful in helping to convey several of the graduate attributes. The knowledge base for engineering was largely addressed by Section 4.2 - Level of Knowledge. In this section, students were asked specific questions regarding timber products, the timber industry, and timber design. Each of the questions posed showed an 
improvement in the level of knowledge after the learning modules were presented to the students.

The impact of engineering on society and the environment was also addressed by Section 4.2 - Level of Knowledge, as well as Section 4.1 - Thoughts on Industry and Trends. The results of the survey questions associated with these sections indicate that students gained a better understanding of the impact of timber construction on the environment and have begun to think about factors they had not thought about previously. As an example of this, sustainability factors were one of the most commonly discussed topics when students were asked why they were in support (or not in support) of the construction of more large and tall timber buildings. As well, when students were asked to name two or three advantages of timber construction, the students discussed durability of the material only after the learning modules had been presented. This shows that not only have students learned about the unique properties of timber, but they have also expanded their thought processes regarding factors that contribute to the sustainability of a material.

Finally, several survey questions addressed the economics and project management graduate attribute. The questions that covered this graduate attribute are discussed in Section 4.1 - Thoughts on Industry and Trends as well as Section 4.2 - Level of Knowledge. An example of this would be the questions that asked students to list two or three advantages and disadvantages of timber construction. Many aspects of economics and project management were referenced in the student responses, including the construction time and material cost.

\section{RECOMMENDATIONS AND CONCLUSIONS}

There is a growing demand for civil engineering graduates who are knowledgeable about timber design and construction, and the method described in this paper offers an efficient means of providing students with the required knowledge without overloading them with additional courses. By integrating timber learning modules within the existing civil engineering curriculum, students are able to graduate in the next few years with some knowledge of timber design, in the time required for entire timber design courses to be developed widely across Canadian universities.

Organizations such as the Canadian Wood Council have provided many materials which significantly facilitate the creation of a timber design course, or even simple timber learning modules such as the ones described above. Lecture slides, course outlines, and design guides are all available for free or are easily accessible to instructors and students. The open stance on resources is extremely helpful to instructors in developing their course content. Continued access to the existing and improved resources will help instructors develop the learning materials they require to educate students.

The survey outlined above showed that the timber learning modules were successful in providing at least some foundational knowledge of timber design. One of the most telling questions is the question that asks students how confident they would be in contributing to the design of a timber building upon graduation, which saw that students gained significant confidence after the learning modules had been presented. This question exemplifies that even though the learning modules presented were short and concise, they were sufficient in providing students with the required skill set to begin to understand timber design problems.

The results of the survey also showed the success of the learning modules at meeting a few of the graduate attributes. A knowledge base for engineering was developed as students expanded their structural engineering knowledge to a material that was entirely new to them. The learning required them to consider the impact of timber construction on the environment and society as well as the economics and project management of a timber design, as timber has many unique properties that must be considered within these various contexts.

Eventually, more civil engineering universities across Canada are likely to begin offering entire courses on timber design. Until that is the case, the method proposed in this paper can be used to allow students to gain basic knowledge. Guest lectures and site visits would be other methods which allow students to further their knowledge of timber design. These methods would complement the learning module method described above but could also be implemented on their own where instructors at a university may not have a background in timber design (and therefore teaching timber learning modules would be challenging).

In order for the learning module method to be completed in two installments (the first in Civil Engineering Materials and the second in Structural Steel Design), Civil Engineering Materials needs to be a prerequisite to Structural Steel Design. Having Civil Engineering Materials as a pre-requisite to design courses in general would be beneficial to the students, as it would give them background to the material mechanics and properties, allowing students to better understand material performance and design. It is therefore recommended that the Civil Engineering Materials course be a pre-requisite to the Structural Steel Design (and other design) courses.

The students have clearly indicated that they are highly interested and motivated to study timber design. This very much aligns with industry demand, as educators it makes sense to provide students with the skills they desire.

\section{Acknowledgements}

Funding provided by York University, through the York University Initiation research grant. Additional thanks to 
the Canadian Wood Council for providing teaching resources.

\section{References}

[1] C Kelz, V Grote, and M Moser, "Interior wood use in classrooms reduces pupils' stress levels," in Proc. $9^{\text {th }}$ International Conference on Environmental Psychology, (Eindhoven, The Netherlands; 26-28 September 2011), 4 pp. 2011.

[2] Canada Commission on Building and Fire Codes, Proposed Change 1023. National Research Council Canada, 2017. Available as of April 29, 2019, from https://www.nrccnrc.gc.ca/obj/doc/solutions-solutions/advisory-

consultatifs/codes_centre-centre_codes/public_reviewexamen public/public review PDFexamen public PDF/2017/NRC PublicReview 2017 NBC N FC NPC combined.pdf

[3] Engineers Canada Consultation Group on Engineering Instruction and Accreditation, Consultation Group - Engineering Instruction and Accreditation Graduate Attributes. Engineers Canada, 2016. Available as of April 29, 2019, from https://engineerscanada.ca/sites/default/files/GraduateAttributes.pdf

[4] Satoshi Sakuragawa, Yoshifumi Miyazaki, Tomoyuki Kaneko, and Teruo Makita, "Influence of wood wall panels on physiological and psychological responses," Journal of Wood Science, vol. 51, pp. 136-140, 2005.

[5] WoodWORKS!, Wood WORKS! eLearning Centre. Canadian Wood Council, 2016. Available as of April 29, 2019, from https://woodworkselearning.com

\section{APPENDIX A: SURVEY QUESTIONS}

The survey questions are presented below. Note that where no options are offered, students were able to input text in a short answer format.

1. How would you rate your interest level in learning about timber design?

- 1 - Not Interested

- 2

- 3

- 4

- 5 - Extremely Interested

2. Why are you interested in timber design?

3. How interested would you be in learning more about timber within your Civil Engineering education?

- 1 - Not interested

- 2

- 3

- 4

- 5 - Extremely Interested

4. If you had the option of taking one of the following courses, which one would you choose?

- Steel Design
- Timber Design

- Hybrid Steel and Timber Design

5. How much do you support the construction of more tall and large timber buildings?

- 1 - I am not supportive of all

- 2

- 3

- 4

- 5 - I am extremely supportive

6. Why do you support/not support the construction of more tall and large timber buildings?

7. Do you think we will see an increase in the number of timber buildings being constructed in the next few years in Toronto?

- Yes, a significant increase

- Yes, a slight increase

- No change from today

- No, a slight decrease

- No, a significant decrease

8. Do you think we will see an increase in the number of timber buildings being constructed in the next few years in Canada?

- Yes, a significant increase

- Yes, a slight increase

- No change from today

- No, a slight decrease

- No, a significant decrease

9. What is engineered timber?

10. Can you name any engineered timber buildings in Toronto or Canada?

11. How familiar are you with different timber products, for example, Cross Laminated Timber, Glued Laminated Timber, etc.?

- 1 - Not familiar at all

- 2

- 3

- 4

- 5 - Very familiar

12. Please explain 2-3 advantages of timber construction. 13. Please explain 2-3 disadvantages of timber construction.

14. Upon graduation, how confident would you be in contributing to the design of a timber building?

- $\quad 1$ - Not confident at all

- 2

- 3

- 4

- 5 - Very confident

15. Do you have any other opinions about timber education or the timber industry in Canada that you would like to share? (Asked only after learning modules had been presented) 